\title{
Varietal Comparison in Relation to Inflorescence Sap Yield and Quality in Coconut
}

\author{
R. S. Raghu ${ }^{1}$ and Biju Joseph ${ }^{2 *}$ \\ ${ }^{1}$ Agricultural College, Bapatla-522101, ANGRAU, India \\ ${ }^{2}$ College of Agriculture, Vellayani-695522, Kerala Agricultural University, India \\ *Corresponding author
}

\section{A B S T R A C T}

\begin{tabular}{l} 
K e y w o r d s \\
Biochemical \\
properties, Coconut \\
inflorescence sap, \\
MYD, Varieties, \\
WCT and Yield \\
\hline Article Info \\
\hline $\begin{array}{l}\text { Accepted: } \\
18 \text { May } 2020 \\
\text { Available Online: } \\
\text { 10 June } 2020\end{array}$ \\
\hline
\end{tabular}

\begin{abstract}
A field experiment was conducted at Nileswaram farm, Regional Agricultural Research Station, Pilicode, Kerala Agricultural University during 2014-2016 to study the Influence of varieties on yield and qualities of coconut inflorescence sap. The varieties tried were Malayan Yellow Dwarf, Kerasree, West Coast Tall and Keraganga. Fully emerged unopened bunches were selected for tapping. The sap yield was measured for the harvesting $21^{\text {st }}$ day after starting of tapping. Sample for chemical analysis were also collected on the same day. From the results it was revealed that the varieties varied significantly with respect to coconut inflorescence sap yield. It was maximum in the tall variety West Coast Tall (3.14 L/day) followed by the hybrid varieties Kerasree (2.09 L/day) and Keraganga (1.80 L/day). The dwarf variety Malayan Yellow Dwarf gave the lowest coconut inflorescence sap yield of $0.84 \mathrm{~L} / \mathrm{day}$. The varieties did not vary significantly with respect to $\mathrm{pH}$ and phenol content of coconut inflorescence sap. Non reducing sugar dominated over reducing sugar in all the varieties. More than $95 \%$ of the total sugars in all varieties were contributed by non reducing sugars. Non reducing sugar content of sap was significantly higher in the dwarf variety Malayan Yellow Dwarf and tall variety West Coast Tall. Reducing sugar was highest in the tall variety West Coast Tall which was on par with hybrid Kerasree and significantly superior to the hybrid Keraganga and dwarf variety Malayan Yellow Dwarf. The varieties West Coast Tall and Malayan Yellow Dwarf were superior with respect to vitamin C content.
\end{abstract}

\section{Introduction}

Coconut inflorescence sap (CIS) is extracted by a method called tapping which involves selective bleeding of unopened coconut inflorescence which is a traditional practice in all coconut growing countries. The exuding sap is a sweet translucent juice, oyster white in colour with high nutritive value. It is a rich source of reducing and non reducing sugars with plenty of minerals and vitamins. It is also a good source of iron, phosphorous and ascorbic acid. The most significant characteristic of coconut inflorescence sap is 
its low glycemic index an indication of the extent of sugar absorbed into the blood which makes it suitable even for consumption for diabetic patients ${ }^{7}$. In recent times there is a huge global demand for low GI sugars while its availability is limited. CIS which is a natural source of low GI sugars can fill up this gap. Studies have revealed that coconut varieties differ with respect to sap yield and quality ${ }^{6}$. It is important to identify varieties having superior sap characteristics for commercial utilization of coconut inflorescence sap. Hence, the present study was undertaken to study the influence of varieties on yield and biochemical properties of coconut inflorescence sap.

\section{Materials and Methods}

The study was conducted at College of Agriculture, Padannakkad and Nileswaram farm, RARS Pilicode under irrigated condition by selecting 4 varieties as treatments namely Malayan Yellow Dwarf $\left(\mathrm{T}_{1}\right)$, Keraganga $\left(\mathrm{T}_{2}\right)$, West Coast Tall $\left(\mathrm{T}_{3}\right)$ and Kerasree $\left(\mathrm{T}_{4}\right)$. A single fully emerged unopened bunch from each variety with similar age and morphological characters were selected and other cultural practices were adopted as per $\mathrm{POP}^{4}$. The bunch was tied at many places to prevent opening of inflorescence and facilitate sap flow by tapping process. The flow started 8 to 12 days after the first cut was made and the flow continues for 40 to 60 days. The collected sap in a plastic container was measured with a measuring cylinder $21^{\text {st }}$ day after starting of tapping and observation as continued for 15 days. During morning, Samples were collected in plastic bottles by keeping for two hours on the bunch. The collected samples were immediately stored in refrigerator and Biochemical analysis were carried out. The $\mathrm{pH}$ of sap was measured using electronic $\mathrm{pH}$ meter $^{16}$. The total electrolyte concentration of sap was measured by using Conductivity
Bridge $^{3}$. The total sugar content of sap was estimated as per the procedure outlined by ${ }^{9}$. The estimation of reducing sugars in sap was done by dinitro salicylic acid (DNS) method $^{19}$. The observation under total sugars and reducing sugars were used for calculating non reducing sugars based on the procedure suggested by ${ }^{14}$ and expressed as percent on fresh weight basis. The vitamin-c content of sap was estimated by the volumetric method $^{15}$. Alcohol content of sap was estimated by titration method using potassium dichromate and sodium thiosulphate ${ }^{21}$ Phenols content was estimated by FolinCiocalteau method ${ }^{8}$. The data obtained were analyzed statistically and difference was tested at $5 \%$ level of significance $(\mathrm{p}<0.05)$.

\section{Results and Discussion}

Results of the experiment on the influence of varieties on yield and qualities of coconut inflorescence sap are presented in Table 1.

\section{CIS yield}

The treatment $\mathrm{T}_{3}$ (West coast tall) recorded the highest CIS yield of 3.141 day $^{-1}$ which was significantly higher than all other treatments. This was followed by $\mathrm{T}_{4}(2.09 \mathrm{l}$ day $\left.^{-1}\right), \mathrm{T}_{2}$ (1.80 $1 \mathrm{day}^{-1}$ ) which were on par. CIS yield was the lowest in $\mathrm{T}_{1}\left(0.841\right.$ day $\left.^{-1}\right)$.

\section{pH and electrolyte concentration}

The $\mathrm{pH}$ of coconut inflorescence sap ranged from $6.6\left(\mathrm{~T}_{2}\right.$ and $\left.\mathrm{T}_{3}\right)$ to $6.8\left(\mathrm{~T}_{1}\right)$. There was no significant difference between the varieties.

The electrolyte concentration of coconut inflorescence sap was significantly influenced by varieties. It was the highest in T3 $(0.21 \mathrm{dS}$ $\left.\mathrm{m}^{-1}\right)$ which was on par with $\mathrm{T}_{4}\left(0.20 \mathrm{dS} \mathrm{m} \mathrm{m}^{-1}\right)$ and $\mathrm{T}_{2}\left(0.19 \mathrm{dS} \mathrm{m}^{-1}\right)$ and significantly higher than $\mathrm{T}_{1}\left(0.18 \mathrm{dS} \mathrm{m}^{-1}\right) . \mathrm{T}_{4}, \mathrm{~T}_{2}$ and $\mathrm{T}_{1}$ were on par. 


\section{Biochemical properties}

\section{Reducing sugars, non reducing sugars and total sugars}

The variety west coast tall $\left(\mathrm{T}_{3}\right)$ recorded the highest reducing sugar content of $0.52 \mathrm{~g}$ $100 \mathrm{ml}^{-1}$ which was on par with the variety

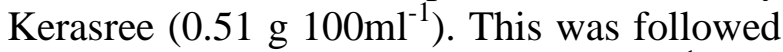

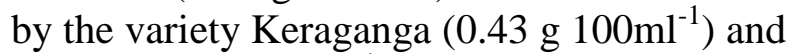

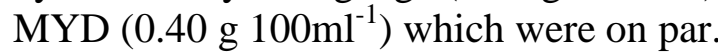

The treatment $\mathrm{T}_{1}$ (MYD) gave the maximum non reducing sugar content of $10.23{\mathrm{~g} 100 \mathrm{ml}^{-1}}^{-1}$ which was on par with $\mathrm{T}_{3}$ (WCT). $\mathrm{T}_{4}$ (Kerasree) recorded the lowest non reducing

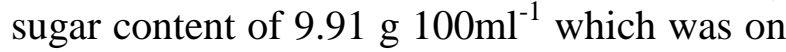
par with $\mathrm{T}_{2}$ (Keraganga).

The highest total sugar content of $10.66 \mathrm{~g}$ $100 \mathrm{ml}^{-1}$ was associated with the variety WCT $\left(\mathrm{T}_{3}\right)$ which was on par with MYD $\left(\mathrm{T}_{1}\right)$ and Keraganga $\left(\mathrm{T}_{2}\right)$. The lowest total sugar content was seen in variety Kerasree (10.42 g $\left.100 \mathrm{ml}^{-1}\right)$.

\section{Alcohol}

Among the treatments, $T_{1}$ (Malayan yellow dwarf) recorded the highest alcohol content of
$0.09 \%$ which was on par with $\mathrm{T}_{4}(0.08 \%)$ and significantly higher than $\mathrm{T}_{3}(0.06 \%)$ and $\mathrm{T}_{2}(0.05 \%)$ which were on par.

\section{Phenol and vitamin C}

There was no significant difference between the treatments with respect to phenol content of coconut inflorescence sap. It was the highest in $\mathrm{T}_{3}\left(5.71 \mathrm{mg} 100 \mathrm{ml}^{-1}\right)$ and the

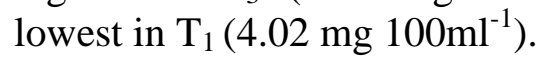

The vitamin $\mathrm{C}$ content of CIS was the highest in $\mathrm{T}_{3}\left(1.87 \mathrm{mg}^{\left.100 \mathrm{ml}^{-1}\right)}\right.$ which was on par with $\mathrm{T}_{1}\left(1.76 \mathrm{mg}^{\left.100 \mathrm{ml}^{-1}\right)}\right.$ and $\mathrm{T}_{4}(1.65 \mathrm{mg}$ $100 \mathrm{ml}^{-1}$ ) and significantly higher than $\mathrm{T}_{2}$

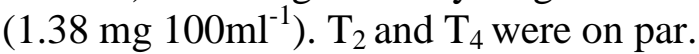

There was no significant difference between the treatments with respect to phenol content of coconut inflorescence sap. It was the highest in $\mathrm{T}_{3}\left(5.71 \mathrm{mg} 100 \mathrm{ml}^{-1}\right)$ and the

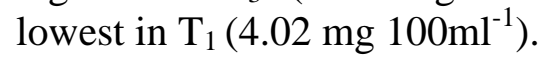

The vitamin $\mathrm{C}$ content of CIS was the highest in $\mathrm{T}_{3}\left(1.87 \mathrm{mg} 100 \mathrm{ml}^{-1}\right)$ which was on par with $\mathrm{T}_{1}\left(1.76 \mathrm{mg}^{\left.100 \mathrm{ml}^{-1}\right)}\right.$ and $\mathrm{T}_{4}(1.65 \mathrm{mg}$ $100 \mathrm{ml}^{-1}$ ) and significantly higher than $\mathrm{T}_{2}$

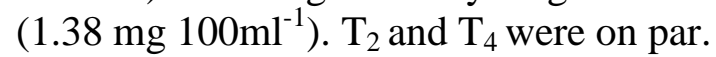

Table.1 Influence of varieties on yield and biochemical properties of coconut inflorescence sap

\begin{tabular}{|c|c|c|c|c|c|c|c|c|c|c|}
\hline $\begin{array}{c}\text { Treatmen } \\
\text { ts }\end{array}$ & $\begin{array}{c}\text { Yield } \\
\left(\text { l day }^{-1}\right)\end{array}$ & pH & \multicolumn{2}{|c|}{$\begin{array}{c}\text { Electrolyte } \\
\text { Concentra } \\
\text { tion } \\
\left(\mathbf{d S ~ ~ m ^ { - 1 } )}\right.\end{array}$} & $\begin{array}{c}\text { Reducing } \\
\text { sugars }(\mathrm{g} \\
\left.100 \mathrm{ml}^{-1}\right)\end{array}$ & $\begin{array}{c}\text { Non- } \\
\text { Reducing } \\
\text { sugars } \\
\left(\text { g 100ml }{ }^{-1}\right)\end{array}$ & $\begin{array}{c}\text { Total } \\
\text { sugars } \\
(\mathrm{g} \\
\left.100 \mathrm{ml}^{-1}\right)\end{array}$ & $\begin{array}{c}\text { Alcoh } \\
\text { ol } \\
(\%)\end{array}$ & $\begin{array}{c}\text { Phenol } \\
(\mathrm{mg} \\
\left.100 \mathrm{ml}^{-1}\right)\end{array}$ & $\begin{array}{c}\text { Vit- c } \\
(\mathrm{mg} \\
\left.100 \mathrm{ml}^{-1}\right)\end{array}$ \\
\hline T1 & \multicolumn{2}{|c|}{0.84} & 6.8 & 0.18 & 0.40 & 10.23 & 10.64 & 0.09 & 4.02 & 1.76 \\
\hline $\mathbf{T} 2$ & \multicolumn{2}{|c|}{1.80} & 6.6 & 0.19 & 0.43 & 10.02 & 10.50 & 0.05 & 5.53 & 1.38 \\
\hline T3 & \multicolumn{2}{|c|}{3.14} & 6.6 & 0.21 & 0.52 & 10.15 & 10.66 & 0.06 & 5.71 & 1.87 \\
\hline T4 & \multicolumn{2}{|c|}{2.09} & 6.7 & 0.19 & 0.51 & 9.91 & 10.42 & 0.08 & 5.56 & 1.65 \\
\hline CD (0.05) & \multicolumn{2}{|c|}{0.26} & NS & 0.02 & 0.03 & 0.19 & 0.18 & 0.01 & NS & 0.30 \\
\hline
\end{tabular}


Fig.1 Influence of varieties on yield and biochemical properties of coconut inflorescence sap

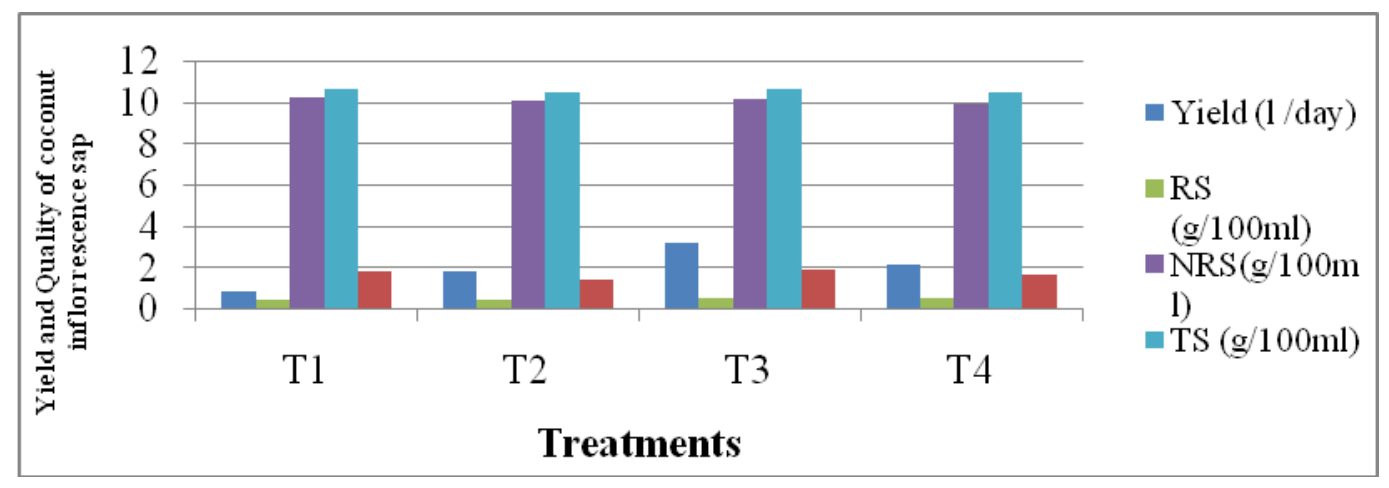

Influence of varieties on yield and biochemical properties of coconut inflorescence sap are presented in Fig. 1.

\section{CIS yield}

The varieties varied significantly with respect to yield of coconut inflorescence sap. The tall variety west coast tall had the highest CIS yield of 3.141 day $^{-1}$ which was significantly higher than the hybrids and dwarf varieties. The two hybrids Keraganga and Kerasree performed on par. However the dwarf variety Malayan yellow dwarf was poor performer with a CIS yield of 0.841 day $^{-1}$. These differences can be attributed to the genetic potentials of the palms. These findings are in agreement with those reported by ${ }^{17}$ who reported that CIS production was maximum in tall variety WCT followed by $\mathrm{D} \times \mathrm{T}$ hybrid and lowest in the dwarf variety COD. ${ }^{2}$ and ${ }^{6}$ also reported same results.

\section{pH and electrolyte concentration}

$\mathrm{pH}$ of CIS did not vary significantly among the different varieties. It remained near neutral in all the varieties. Similar results were reported by ${ }^{12}$. Further ${ }^{2}$ also reported that fresh coconut inflorescence sap has a nearly neutral $\mathrm{pH}$. The electrolyte concentration of CIS was observed to be significantly varying among the varieties. It was highest in WCT $\left(0.21 \mathrm{dS} \mathrm{m}^{1}\right)$, which was on par with
Keraganga (0.19 dS $\left.\mathrm{m}^{-1}\right)$ and Kerasree (0.19 $\mathrm{dS} \mathrm{m}^{-1}$ ) and significantly higher than MYD $\left(0.18 \mathrm{dS} \mathrm{m}^{-1}\right)$. This can be interpreted to the higher concentration of reducing sugars, non reducing sugars, total sugars and phenols associated with this treatment.

\section{Biochemical properties}

The varieties differ significantly with respect to reducing sugars, non reducing sugars and total sugars. This was in line with the findings of $^{5}$ who reported that the sugar content of CIS depends on coconut ecotypes. Non reducing sugar dominated over reducing sugar in the case of all the varieties. More than $95 \%$ of the total sugars in all the varieties were contributed by non reducing sugars. This is harmony with the findings of 10 and 5 who observed that carbohydrates of unfermented CIS had a greater proportion of sucrose. Similar results were also reported by ${ }^{1}$. Reducing sugar was highest in tall variety WCT which was on par with the hybrid Kerasree and significantly superior to the hybrid Keraganga and the dwarf variety Malayan yellow dwarf. The presence of small quantity of reducing sugars in the sap from all the varieties can be attributed to two biochemical processes. The first source might be the enzymatic hydrolysis of sucrose during fermentation of sap which starts spontaneously by microorganisms in the sap, while the second source could be 
physiological synthesis of reducing sugars by the coconut palms during photosynthesis. Similar results were also reported by ${ }^{5}$. The non reducing sugar content of sap was significantly higher in the dwarf variety MYD which was on par with WCT and significantly superior to the hybrids Kerasree and Keraganga. Similar results have been reported by ${ }^{18}$ and ${ }^{12}$ who found that dwarf varieties have more non reducing sugars than tall varieties and hybrids. The highest total sugar content was associated with the variety WCT which was on par with Malayan yellow dwarf and Keraganga. It should be noted that even though the dwarf variety had poor sap production potential, it was superior with respect to concentration of non reducing sugars and total sugars. This indicates more intensive sugar synthesis in dwarf coconut palms. The dwarf palms have weak root system that might not enable good mineral uptake. Consequently for their survival the dwarf coconut palms could achieve an intensive photosynthesis leading to higher production of carbohydrates which has reflected as higher non reducing sugar and total sugar in sap. Similar results were also reported by ${ }^{5}$.

The CIS from the different varieties had alcohol content ranging from $0.09 \%$ (MYD) to $0.04 \%$ (WCT). ${ }^{18}$ also reported that fresh CIS contains $0.2 \%$ alcohol. There was a significant variation in alcohol content of CIS with varieties. The presence of alcohol in the sap of all varieties can be attributed to the fact that fermentation of sap starts right from the secretion of the first drop of sap as the CIS has a high load of yeast. Similar results were reported by ${ }^{13}$ who attributed the presence of alcohol in fresh coconut inflorescence sap to the presence of naturally present yeast in the sap which would have spontaneously started fermentation of sap even while still in the tapping process. This highest alcohol content was associated with the dwarf variety Malayan yellow dwarf which was on par with
Kerasree. Rather than the inherent genetic characters of the palm, the higher alcohol content can be attributed to the higher concentration of non reducing sugars which would have provided more substrate for yeast fermentation.

Phenol content in CIS ranged from $4.02 \mathrm{mg}$ $100 \mathrm{ml}^{-1}$ (MYD) to $5.71 \mathrm{mg} 100 \mathrm{ml}^{-1}$ (WCT). Similar results were reported by ${ }^{11}$ who reported that Keramritham (Neera) contains $8.0 \mathrm{mg} 100 \mathrm{ml}^{-1}$ of phenols and ${ }^{20}$ who observed a total phenolic content of $0.34 \mathrm{~g} \mathrm{l}^{-1}$ in fresh coconut inflorescence sap. There was no significant variation among the varieties with respect to phenol content of sap. There was a significant influence of varieties on vitamin $\mathrm{C}$ content of CIS. The highest value was in the variety WCT which was on par with MYD and Kerasree. The source of vitamin $\mathrm{C}$ in the sap is from the yeast fermentation of sugar present in the sap. The highest vitamin $\mathrm{C}$ content in the variety WCT and MYD may be attributed to the higher non reducing sugar and total sugar seen in these varieties which would have facilitated faster fermentation and higher production of vitamin C. In similar studies ${ }^{2}$ observed $17.5 \mathrm{mg}$ $100 \mathrm{ml}^{-1}$ of vitamin $\mathrm{C}$ and ${ }^{20}$ reported $20.6 \mathrm{mg}$ $\mathrm{I}^{-1}$ of vitamin $\mathrm{C}$ in fresh coconut inflorescence sap.

In conclusion, the varieties varied significantly with respect to CIS yield. It was maximum in the tall variety WCT (3.14 1 day $^{-1}$ ) followed by the hybrid varieties Kerasree (2.09 $1 \mathrm{day}^{-1}$ ) and Keraganga (1.80 1 day $\left.^{-1}\right)$. The dwarf variety MYD gave the lowest CIS yield of 0.841 day $^{-1}$. The variety WCT was superior with respect to reducing

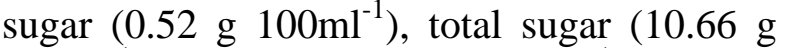
$\left.100 \mathrm{ml}^{-1}\right)$, phenols $\left(5.71 \mathrm{mg} 100 \mathrm{ml}^{-1}\right)$, vitamin

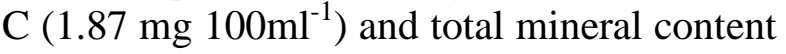
$(2.32 \%)$ while the dwarf variety MYD gave

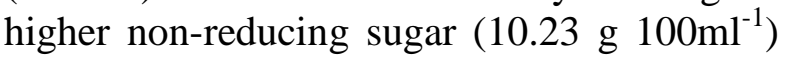
and alcohol $(0.09 \%)$. 


\section{Acknowledgement}

I feel immense pleasure to express my profound and heartfelt thankfulness to my parents, Dr. Biju Joseph (Chairman of the advisory committee) and KAU.

\section{Conflict of interest}

The authors declares that there is no conflict of interests regarding the publication of this paper

\section{References}

1. Barh, D. and Mazumdar, B.C. 2008. Comparative Nutritive Values of Palm Saps Before and after Their Partial Fermentation and Effective Use of Wild Date (Phoenix sylvestris Roxb.) Sap in Treatment of Anemia. J. Medicine Med Sci. 3: 173-176.

2. Hebbar, K.B., Arivalagan, M., Manikantan, M. R., Mathew, A. C., Thamban, C., George Thomas, V. and Chowdappa, P. 2015. Coconut inflorescence sap and its value addition as sugar - collection techniques, yield, properties and market perspective. Curr. Sci. 109 (8): 121-126.

3. Jackson, M.L. 1958. Soil Chemical Analysis. Prentice-Hall, University of wiscinsin, Madison, 498p.

4. KAU (Kerala Agricultural University). 2011. Package of Practices Recommendations: crops $\left(14^{\text {th }}\right.$ Ed.), Kerala Agricultural University, Thrissur, 256p.

5. Konan, N.Y., Assa, R.R., Konan, K.J.L., Okoma, D.M., Prades, A., Allou, K. and Biego, G.H.M. 2014. Glucide factors of the inflorescence sap of four coconut (Cocos nucifera L.) cultivars from Côte d'Ivoire. Inter. J. Biochem. Res.Rev. 4(2): 116-127.

6. Konan, N.Y., Konan, K.J.L., Assa, R.R.,
Konan, B.R., Okoma, D.M.J., Allou, K. and Biego, G.M.H. 2013. Assessment of sap production parameters from spathes of four coconut (Cocos nucifera L.) cultivars in Côte d'Ivoire. Sustain. Agric. Res. 2(4): 87-94.

7. Manohar, E.C., Kindipan, N.M.L. and Sancha, L.V. 2007. Coconut sap sugar production: From farm to market and from wealth to health, Philipp. Entomologists 32 (1): 20.

8. Mayr, U., Funfgelder, S., Treutter, D. and Feucht, W. 1995. Induction of phenol accumulation by pesticides under the control of environmental factors. In: Manka M. (ed.) Environmental Biotic Factors in Integrated Plant Disease Control. Polish Phytopathological Society, Varsaw, Poland pp. 399-402.

9. McCready, R.M., Guggolz, J., Silviera, V. and Owens, H.S. 1950. Determination of starch and amylose in vegetables. Anal. Chem. 22: 1156.

10. Michael, O., Eze, A. and UzoechiOgan. 1988. Sugars of the unfermented sap and the wine from the oil palm, Elaeisguinensis tree. Plant Foods for Hum.Nutr. 38: 121-126.

11. Naik, J.B., Suresh, P.R., Manjusha, M., Balachandran, P.V., Madhusubramonian, and Balakrishnan, P.C. 2013. Keraamritham - a health drink from coconut inflorescence sap. Indian Coconut J. 4(2): 9-14.

12. Nakamura, S.I., Watanabe, A., Chongpraditnum, P., Suzui, N., Hayashi, H. and Mitsuo, C. 2004. Analysis of phloem exudate collected from fruit-bearing stems of coconut palm: Palm trees as a source of molecules circulating in sieve tubes. Soil Sci. Plant. Nutr. 50(5): 739-745.

13. NurAimi, R., Abu Bakar, F. and Dzulkifly, M. H. 2013. Determination of volatile compounds in fresh and fermented Nipa sap (Nypa fruticans) 
using static headspace gas chromatography-mass spectrometry (GC-MS) Int. Food Res J. 20(1): 369376.

14. Ranganna, S. 1977. Hand book of analysis and quality control for fruit and vegetables products. Tata McGraw- Hill publishing company Ltd. New Delhi. India. 1112p

15. Sadasivam, S. and Manickam, A. 2008. Biochemical methods, (Second edition). New Age International Publishers, New Delhi, 256 p.

16. Saini, R.S., Sharma, K.D., Dhankar, O.P., and Kaushik, R.A. 2001. Laboratory Manual for Analytical Techniques in Horticulture. Agro. Bios. India. 135p.

17. Samsudeen, K., Niral, V., Jerald, B.A., Kumar, M., Sugatha, P. and Hebbar,
K.B. 2013. Influence of variety and season in the inflorescence sap production in Cocos nucifera L. J. Plant. Crops 41(1): 57-61.

18. Singaravadivel, K., Alagusundaram, K., and Hariharan, B. 2012. Physicochemical Properties of Fresh and Stored Coconut Palm Toddy. 1: 397p.

19. Somogyi, M. 1952. Notes on sugar determination. J. Biol. Chem. 195: 1923.

20. Syamala Devi, N., Hariprasad, T., Ramesh, K. and Ramachander, M. 2015. Antioxidant properties of coconut sap and its sugars. Int. J. Pharmtech Res. 8 (1): 160-162.

21. William, M.B. and Darwin, R. 1950. Colorimetric determination of ethyl alcohol. Anal. Chem. 22: 1556-1561.

\section{How to cite this article:}

Raghu, R. S. and Biju Joseph. 2020. Varietal Comparison in Relation to Inflorescence Sap Yield and Quality in Coconut. Int.J.Curr.Microbiol.App.Sci. 9(06): 1022-1028. doi: https://doi.org/10.20546/ijcmas.2020.906.127 